\title{
Cytological investigations on populations of Taraxacum (Asteraceae) from the Juan Fernandez Archipelago, Chile
}

\author{
Investigaciones citológicas en poblaciones de Taraxacum (Asteraceae) del Archipiélago \\ de Juan Fernández, Chile
}

\author{
Carlos Baeza $^{1 *}$, Cristián Bastías ${ }^{1}$, Tod Stuessy², Eduardo Ruiz ${ }^{1}$, Josef Greimler ${ }^{2}$, Patricio López- \\ Sepulveda ${ }^{2}$, Patricio Peñallillo ${ }^{3}$, Patricio Novoa ${ }^{4}$ \& Alejandro Gatica ${ }^{3}$
}

1Departamento de Botánica, Universidad de Concepción, Barrio Universitario s/n, Casilla 160-C, Concepción, Chile.

${ }^{2}$ Department of Systematic and Evolutionary Botany, Biodiversity Center, University of Vienna, Austria.

${ }^{3}$ Departamento de Biología Vegetal y Biotecnología, Universidad de Talca, Talca, Chile.

${ }^{4}$ Jardín Botánico, Corporación Nacional Forestal, Viña del Mar, Chile.

*cbaeza@udec.cl

\begin{abstract}
RESUMEN
Durante una expedición al Archipiélago de Juan Fernández, Chile, en febrero de 2011, se recolectaron semillas de Taraxacum fernandezianum Dahlst. provenientes de las islas Robinson Crusoe y Alejandro Selkirk. Se realizó un análisis citológico de las dos poblaciones y se concluyó que ambas son triploides, con un $2 n=3 \mathrm{x}=24$ cromosomas, con una fórmula cariotípica de $18 \mathrm{~m}+3 \mathrm{sm}+3 \mathrm{sm}$-sat, esto es, 18 cromosomas metacéntricos, 3 cromosomas submetacéntricos y 3 cromosomas submetacéntricos con un satélite en el brazo largo. Coincidentemente, estas poblaciones son citológicamente idénticas a las reportadas en Japón e India para Taraxacum officinale. Sobre estos antecedentes, concluimos que desde un punto de vista citológico Taraxacum fernandezianum podría ser considerado como Taraxacum officinale, maleza ampliamente distribuida en todo el mundo.
\end{abstract}

The Juan Fernández (Robinson Crusoe) Archipelago is located in the Pacific Ocean, $670 \mathrm{~km}$ west of Valparaiso, Chile. The archipelago consists of three islands of volcanic origin: Robinson Crusoe (Más a Tierra), Alejandro Selkirk (Más Afuera), and Santa Clara (Baeza et al. 2007). The flora of these islands is notable for its high level of endemism, among the vascular plants $60 \%$ of the species and $11 \%$ of the genera (Stuessy et al. 1992). During a recently completed expedition to the two major islands in February 2011, two populations of Taraxacum fernandezianum were collected, one from each island. This species is considered native to continental and insular Chile (Marticorena \& Quezada 1985), and it also occurs in Argentina, Bermuda, Brazil, Costa Rica, Dominican Republic, Guatemala, Haiti, Honduras, and Peru (Richards 1976). The genus Taraxacum is known to comprise about 2500 species grouped in 40 sections (Kirschner \& Stepanek 1994).

In addition to Taraxacum fernandezianum, T. gilliesii H. \& A. and T. officinale Weber have been listed for Chile (Marticorena \& Quezada 1985). Uhlemann et al. (2004) commented on the broad range of phenotypic variation (and plasticity) of species of Taraxacum in Patagonia, specifically in and around Seno Otway, Punta Arenas, indicating large differences in the form and division of the leaves. These authors also found that Taraxacum gilliesii, a native species to Patagonia, has a chromosome number of $2 n=16$, obtained from a plant that reproduces sexually.

Cytological studies have also been completed on alpine species of Taraxacum in Europe, where the species consist of diploids, triploids, and mostly tetraploids (Richards 1972, Stepanek et al. 2001). Cytological observations also have been made on Taraxacum officinale. Sato et al. (2007) completed a cytogenetic study of five cytotypes of $T$. officinale triploids from Japan, observing that only cytotype 1 corresponded to T. officinale, the other four types representing hybrids. Type 1 has a karyotypic formula of $2 n=24=1 \mathrm{M}+17 \mathrm{~m}+3 \mathrm{sm}+3 \mathrm{sm}$-sat. Fazili et al. (2011) studied the karyotype of a population of $T$. officinale from India, documenting that these plants have $2 n=3 \mathrm{x}=24$, with chromosomes less than 2.5 microns and with a karyotypic formula consisting of 18 metacentric and 6 submetacentric chromosomes.

Cytology provides a type of data that can be helpful in resolving taxonomic problems, and their efficacy is well known, especially in genera where the floral morphology is not adequate or in which there exists high phenotypic variation (Stuessy 2009). The objective of this paper, therefore, is to document the karyotype of the two populations of Taraxacum fernandezianum occurring on the Juan Fernandez Archipelago, and to compare results with 
those previously published for species of the genus known from Chile.

Mature seeds were collected from a population on Alejandro Selkirk Island, Quebrada Las Chozas, $520 \mathrm{~m}$, $33^{\circ} 45^{\prime} \mathrm{S} / 80^{\circ} 46^{\prime} \mathrm{W}, 4 \mathrm{Feb} 2011$, C. Baeza 4341 (CONC), and from a population from Robinson Crusoe Island, San Juan Bautista, street La Pólvora, 30 m, 33³8'S; 78 $50 \mathrm{~W}$, 22 Feb 2011, C. Baeza 4342b (CONC). The population on Alejandro Selkirk occurred in a very humid and shady habitat, covered with closed vegetation. The plants were large, with elongated leaves and a long peduncle. In contrast, the plants on Robinson Crusoe were stunted and with a short peduncle, occurring in a typically disturbed habitat. Morphological comparisons were made of achenes from the same populations that were analyzed cytologically, plus additional populations from the continent. In all cases, no differences in size, color, or ornamentation of the fruits were observed.

This cytological study followed the methods used by Baeza et al. (2009). Mitotic metaphase plates were observed and photographed using a Zeiss Axioskop microscope, with attached monochrome video camera. The software Paint Shop Pro X2 was used to improve the quality of the images; for measuring the chromosomes the software MicroMeasure 3.3 (Reeves 2001) was used. Chromosomes were characterized following the methods proposed by Levan et al. (1964). The idiogram was completed by using the software Corel Draw 8.

The two analyzed populations showed $2 n=3 \mathrm{x}=24$ chromosomes (Fig. 1A, B), with the karyotypic formula $18 \mathrm{~m}+3 \mathrm{sm}+3 \mathrm{sm}$-sat, that is, 18 metacentric chromosomes, 3 submetacentric chromosomes, and 3 submetacentric chromosomes with a satellite on the long arm (Fig. 1C, D). The size of the chromosomes varied between 2.45 and 1.45 $\mu \mathrm{m}$ (Table I).

Coincidentally, the values obtained for Taraxacum fernandezianum in both populations were identical to those documented by Sato et al. (2007) for T. officinale from Japan. This species is characterized by having $2 n=3 \mathrm{x}=24$, that is, a triploid species, with most of the chromosomes being metacentric and with a satellite on the long arm of chromosome 1, which is submetacentric; this characteristic is also found in the two insular populations analyzed (Fig. 1 A-D), besides also being triploid populations. Fazili et al. (2011) also indicated a symmetric karyotype for Taraxacum officinale from India, with $2 n=3 x=24$, with practically the same karyotypic formula found in the island populations, with the exception of the position of the centromeres. Nevertheless, the number of chromosomes, and also the type of chromosomes and the karyotypic formula, are identical to those encountered in Juan Fernandez. Taking into account these data, plus considering that $T$. officinale is a weed widely distributed throughout the world, with a high plasticity of eco-physiological features (Molina-
Montenegro et al. 2009), we conclude that from a cytotaxonomic point of view, the populations sampled in the Juan Fernandez archipelago, Chile, could correspond to Taraxacum officinale. Nevertheless, to corroborate this assertion, it would be necessary to complete a comparative study that would include a larger number of populations from Robinson Crusoe and Alejandro Selkirk, and to utilize data from cytology, comparative morphology, and nuclear and chloroplast DNA sequences. If we consider that Taraxacum fernandezianum corresponds to the common T. officinale, then this will reduce the number of native species in the Juan Fernandez Archipelago (a Biosphere Reserve). Nevertheless, one of the principal objectives of cytotaxonomy is to clarify the taxonomic status of species through utilization of chromosomal evidence, always remembering the vital role that morphology continues to play.

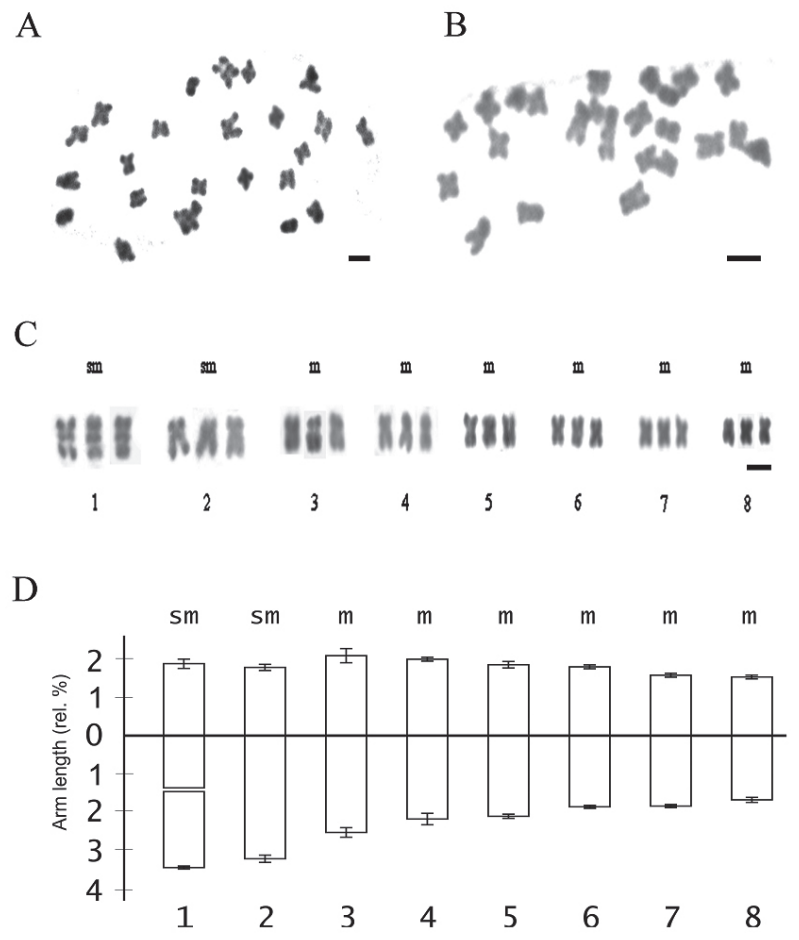

FIgURE 1. Karyotypes of Taraxacum fernandezianum. A. Metaphase plate from Robinson Crusoe Island, Baeza 4342b. B. Metaphase plate from Alejandro Selkirk Island, Baeza 4341. C. Karyotype, Baeza 4341. D. Idiogram, Baeza 4341. Scale $=2 \mu \mathrm{m}$.

FIgURA 1. Cariotipos de Taraxacum fernandezianum. A. Placa metafásica de Taraxacum fernandezianum de Robinson Crusoe, Baeza 4342b. B. Placa metafásica de Taraxacum fernandezianum de Alejandro Selkirk, Baeza 4341. C. Cariotipo, Baeza 4341. D. Idiograma, Baeza 4341. La escala corresponde a $2 \mu \mathrm{m}$. 
Cytology of Taraxacum fernandezianum: BAEZA, C. ET AL.

TABLE I. Chromosome measurements of Taraxacum fernandezianum Dahlst. (Baeza 4341). Relative length is calculated as a per cent of the length of the haploid genome taken from ten metaphases.

TABla I. Mediciones cromosómicas de Taraxacum fernandezianum Dahlst. (Baeza 4341). Se detallan las longitudes promedio como porcentaje de la longitud del genoma haploide de 10 metafases.

\begin{tabular}{lcccccc}
\hline Chromosome & $\begin{array}{c}\text { Long arm } \\
(\%) \pm \text { D.S. }\end{array}$ & $\begin{array}{c}\text { Short arm } \\
(\%) \pm \text { D.S. }\end{array}$ & $\begin{array}{c}\text { Relative length } \\
(\%)\end{array}$ & $\begin{array}{c}\text { Total length } \\
(\mu \mathrm{m})\end{array}$ & $\begin{array}{c}\text { Ratio of the } \\
\text { ARms }(\mathrm{L} / \mathrm{C})\end{array}$ & $\begin{array}{c}\text { Type OF } \\
\text { Chromosome }\end{array}$ \\
\hline 1 & $3,43 \pm 0,04$ & $1,90 \pm 0,24$ & 5,33 & 2,45 & 1,81 & $\mathrm{sm}$-sat \\
2 & $3,21 \pm 0,19$ & $1,78 \pm 0,16$ & 4,99 & 2,29 & 1,80 & $\mathrm{sm}$ \\
3 & $2,52 \pm 0,25$ & $2,08 \pm 0,37$ & 4,60 & 2,11 & 1,21 & $\mathrm{~m}$ \\
4 & $2,17 \pm 0,30$ & $1,99 \pm 0,10$ & 4,16 & 1,91 & 1,09 & $\mathrm{~m}$ \\
5 & $2,12 \pm 0,11$ & $1,87 \pm 0,17$ & 3,99 & 1,83 & 1,13 & $\mathrm{~m}$ \\
6 & $1,85 \pm 0,03$ & $1,79 \pm 0,07$ & 3,64 & 1,67 & 1,03 & $\mathrm{~m}$ \\
8 & $1,83 \pm 0,07$ & $1,57 \pm 0,09$ & 3,40 & 1,56 & 1,17 & $\mathrm{~m}$ \\
\hline
\end{tabular}

\section{ACKNOWLEDGEMENTS}

We are most grateful for help from the following persons and institutions: Sr. Ivan Leiva, the Chief of Robinson Crusoe National Park who facilitated our work in many ways, arranging logistics, guides, etc.; the CONAF guides who have been fundamental in our field work, especially Danilo Arredondo, Bernardo and Juanita López; the people of Alejandro Selkirk Island, who took a great interest in our work in the island; and the Chilean Navy (Armada de Chile) for help in transporting materials from Valparaiso to the archipelago in support of our expeditions.

\section{BIBLIOGRAPHY}

Baeza, M., C. Marticorena, T. Stuessy, E. Ruiz \& M. Negritto. 2007. Poaceae en el archipiélago de Juan Fernández (Robinson Crusoe). Gayana Botánica 64: 125-174.

Baeza, M., E. Ruiz \& M. Negritto. 2009. Importancia del cariotipo en la taxonomía y evolución del género Chaetanthera (Asteraceae): evidencias preliminares para especies que crecen en Chile. Gayana Botánica 66: 50-57.

Fazili, K., Y. Ali, S. Hussain, A. Andrab \& B. Wafai. 2011. Karyotype of apomictic Dandelion (Taraxacum officinale), a wild plant with high medicinal value. Recent Research in Science and Technology 3(10): 118-121.

Kirschner, J. \& J. StepaneK. 1994. Clonality as a part of the evolution process of Taraxacum. Folia Geobotanica 29: 265-275.

Levan, A., K. Fredga \& A. Sandberg. 1964. Nomenclature for centromeric position on chromosomes. Hereditas 52: 201-220.
Marticorena, C. \& M. Quezada. 1985. Catálogo de la flora vascular de Chile. Gayana Botánica 42: 1-157.

Molina-Montenegro, M., L. Cavieres \& L. Corcuera. 2009. ¿Rasgos ecofisiológicos pueden explicar el éxito de la planta invasora Taraxacum officinale sobre un amplio gradiente latitudinal? Brasilian Journal of Ecology 5: 2531.

Reeves, A. 2001. MicroMeasure: a new computer program for the collection and analysis of cytogenetic data. Genome 44: 239-443.

Richards, A. 1972. The karyology of some Taraxacum species from alpine regions of Europe. Botanical Journal of the Linnean Society 65: 47-59.

Richards, A. 1976. An account of some Neotropical Taraxacum. Rhodora 78: 683-706.

Sato, K., Y. Iwatsubo, M. Watanabe, S. Serizawa \& N. Naruhashi. 2007. Cytogenetic study of japanese triploid Taraxacum officinale (common dandelion: Asteraceae). Cytologia 72: 475-482.

StepaneK, J., J. Kirschner, V. Jarolimova \& L. Kirschnerova. 2011. Taraxacum nigricans, T. alpestre and allies in the Taraxacum sect. Alpestria: taxonomy, geography and conservation status. Preslia 83: 537-564.

Stuessy, T. 2009. Plant Taxonomy: The Systematic Evaluation of Comparative Data, ed. 2. Columbia University Press, New York.

Stuessy, T., C. Marticorena, R. Rodríguez, D. J. Crawford \& M. SILVA. 1992. Endemism in the vascular flora of the Juan Fernandez Islands. Aliso 13: 297-307.

Uhlemann, I., J. Kirschner \& J. Stepanek. 2004. The genus Taraxacum (Asteraceae) in the southern hemisphere. I. The section Antarctica Handel-Mazzetti and notes on dandelions of Australasia. Folia Geobotanica 39: 205-220.

Recibido: 17.07 .12

Aceptado: 12.04.13 